DOI: https://doi.org/10.37634/efp.2021.12.4

UDC 330.322:330.341.1

\author{
Kateryna PASTUSHENKO \\ student, Odessa Polytechnic National University \\ ORCID: https://orcid.org/0000-0002-4604-694X
}

Adil Mohamed Abdalla Sultan AL ALI
postgraduate student, Odessa Polytechnic National University
ORCID: https://orcid.org/0000-0001-6577-6289

Viktor ZAMLYNSKYI

Doctor of Economics, Professor, Odessa Polytechnic National University

ORCID: https://orcid.org/0000-0001-7642-2443

e-mail: zam.agrariy@gmail.com

\title{
PROSPECTS OF VENTURE INVESTMENT INNOVATIVE ACTIVITY IN MODERN CONDITIONS OF SUSTAINABLE DEVELOPMENT
}

Sustainable development of the country's economy depends on the level of innovation of each enterprise. Enterprises have an unsatisfactory level of innovative development and their strategies do not meet the goals of sustainable development, which is a consequence of many years of erroneous approaches to the management of enterprises and the country's economy. In modern conditions, venture investment is able to overcome the negative trends caused by insufficient funding, low level of interest of business management in innovations with a high level of risk. The paper substantiates the relevance of attracting venture capital for the development of innovative activities of enterprises. It is analyzed how venture investment differs from the usual. The current state and trends of venture investment in Ukraine have been carefully studied. Problems and obstacles to the functioning of the domestic venture business have been identified. Based on the obtained research results and taking into account the best foreign experience, a comprehensive step-by-step technology of attracting venture capital by innovative enterprises on the basis of sustainable development has been formed. The stages of venture financing and the activity of a venture company in general, mechanisms and incentives for increasing interest in the implementation of innovations in accordance with the goals of sustainable development at the enterprise level are considered. The influence of venture entrepreneurship on the innovative activity of companies is investigated. Also, attention is focused on how the venture manager manages the organization. The ways of formation, disadvantages and advantages of using venture capital at the globalized stage of development as a means of promoting new products and technologies on world markets in the context of sustainable socio-economic development are proposed. The paper considers the current state of venture investment and identifies areas for further development in the development of socio-economic system.

Keywords: venture capital, investment resources, innovation-investment mechanism, sources of project financing, venture investments, innovations, management, risk management, economic development

\section{FORMULATION OF THE PROBLEM}

Venture business is an important element in scientific and technological progress and is widely used in foreign practice. Investors are closely monitoring the recovery of the market and waiting for the moment when the projected profit will overcome the obstacles of possible risks. At each stage there are players who try to use the patterns of economic development through the redistribution of significant financial resources between different financial centers and industries. The problem of venture business management is relevant in today's high-risk economic environment, as venture capital is the main source of innovation, which contributes to the development of new technologies and increase the competitiveness of the country's economy. As the development of innovation requires high analytical costs and is associated with high risk, due to the fact that not all innovations are justified over time, venture capital is the main source of funding. Therefore, in order to effectively invest in innovation in this business, there are managers. Their main function is to manage the risks that arise when working with venture innovation projects. This is an important component of the success of a venture business. How well risk management will be carried out depends not only on whether investors will receive a return on investment, but also on whether new competitive products will appear on the market.

The PURPOSE of the paper is to study the current state of the venture capital management process and to study how it affects innovation.

\section{Analysis of recent research and publications}

The topic of venture capital is not yet widely disseminated and researched in our literature. The urgency of the topic is to improve the Ukrainian economy through the development of innovation in its enterprises. This will not only increase the country's competitiveness in the world market, but also improve its performance in the field of scientific and technological progress. Stabilization of the economic situation necessitates the formation of fundamentally new areas of innovation, development of marketing strategy for financial recovery, based on the historical geoeconomic situation, available resources and production base, government support and available human resources. The implementation of the strategy of sustainnable development is possible on the basis of support of national producers, implementation of public-private partnership projects aimed at import substitution, which will create new jobs, increase budget revenues and incomes of Ukrainian citizens. These processes take place in the context of the variability of world economies. But still, many of the domestic scientists are engaged in research on this issue, it is, V.G. Gerasymchuk [1], V.S. Petrenko, M.I. Kareba, 
N.V. Drill, et al.

\section{PRESENTING MAIN MATERIAL}

The word "venture" is translated from English as risk or risk venture. Venture business is a risk business, that has become the main form of technological innovation, which is characteristic of the conditions of commercialization of research results in knowledge-intensive industries, increasing the risk of capital investment in innovation. Investors take care of 10 projects, two of which will be insufficiently profitable, about three will bring a small income and only some of them have a reasonable income or an income that significantly exceeds the invested financial resources, venture capital (or venture capital investment). Venture capital investment in the world remains one of the most important sources of capital for companies whose rapid growth and sustainable development constantly requires additional foreign investment. Venture funds are a pool of money that is raised from outside investors and that is invested in various startups with the help of fund managers. Investors from whom funds are raised are called Limited partners. They can be either institutional investors: pension funds, trust funds, etc. Or it's wealthy people - people who want to attract riskier assets to their portfolios, thereby investing in venture funds that invest in startups.

Venture Fund Manager - General partner. Its task is to raise a venture fund, find investors and attract money from them. Find the best startups, give money, help them grow and raise income for investors. Thus, if a company provides venture capital, it is a form of investing in innovative activities of enterprises only for a promising idea. That is, venture investors do not receive movable or immovable property, do not have guarantees in the form of savings of the enterprise. This is what distinguishes a venture business from a simple investment. Venture capitalists receive collateral only in the form of a share that is less than the controlling stake of the recipient, i.e. the one, who needs to receive venture capital.

Today, the classic venture investors in Ukraine are primarily single venture funds and investment companies, business incubators and accelerators, business angels and entrepreneurs. So far, there are very few venture funds, but they are ready to consider and support various areas of Ukrainian investment projects and are focused on both domestic and global markets. Among the most active venture funds that are considering investment opportunities in Ukraine are the following: TA Venture, Imperious Group, AVentures Capital, Detonate Ventures, Decarta Capital, Vostok Ventures, Global Technology Foundation, Bukovyna Venture Fund.

In Ukraine, there is a significant demand for venture capital investments, but often the initiators of investment projects are not ready to offer quality investment products. Venture investors in Ukraine face the problem of quality of preparation and viability of investment projects. Venture capitalists typically use a professional approach to selecting investment projects. And the level of financial and economic literacy of the initiators and the quality of preparation of documentation for most projects are insufficient.

The Ukrainian investment and innovation system is not yet ripe for building a venture business model. The main reasons for this are related to the problems of the domestic investment climate, underdeveloped capital market, the predominance of low technological standards in the national economy, imperfection of the legal system in the field of venture investment, low business transparency, limited number of real investment attractive and innovative proposals. And Ukrainian entrepreneurs and investors are not ready to build a venture business of the European model. All this creates a national task to increase the role of classic venture business in building a new model of Ukraine's economy, which will be based on investment and innovation approach.

The venture financing provided by this business is a long-term loan without any guarantees of repayment. Venture business is an economic financing instrument for the commissioning of companies, their development, as well as the acquisition by the investor in the restructuring of their property.

The venture financing process consists of four stages. These stages correspond to how the project is implemented. At the first stage, certain funds are received to refine the idea and develop a business plan for innovation. The second is the use of these funds to prepare production and release new products to specific customers in order to gain their trust and further receive more orders. The third stage involves the cost of finance to expand production, improve product quality, expand the market. And the fourth is final, here is the "exit" of venture capital from the company, by selling its share or selling investments to a particular investor.

Objects of venture activity include: intellectual property, innovation processes, venture projects, agreements between business entities, shares of venture companies and more. The subjects include inventors or entrepreneurs engaged in innovation, venture investors, venture funds, internal and external venture structures and consumers of products obtained through venture activities.

Venture business is closely linked to innovation. Its importance lies not only in the financing of innovations, but also in the formation of innovation and investment mechanisms. In addition, venture enterprises, by developing new technologies and products, significantly help to save resources in the future, as it reveals a hopeless way to develop research. The advantages also include how they affect competition in the market. By bringing new products to market, venture companies encourage large organizations to innovate.

Venture activity also has four stages, which are presented in the figure below (Fig. 1). The first stage, called "Attracting venture capital funds" involves the search for and formation of sources that will provide investment funds in the future. The second stage is the transformation of venture capital and other resources, such as: material and intellectual, into raw materials, i.e. new projects through which venture activities are carried out. The third stage means an increase in the price at which a certain object of venture activity will be sold, at the expense of used venture investments. And the last, fourth stage, is to achieve the goals of this activity, i.e. to obtain a certain effect of the venture business and its other objects. 


\begin{tabular}{|c|}
\hline Stage 1. Attracting venture capital funds \\
\hline Stage 2. Venture capital investment \\
\hline $\begin{array}{c}\text { Stage 3. Transformation of investment resources into } \\
\text { capitalization of market values of enterprises }\end{array}$ \\
\hline \\
\hline Stage 4. Income by venture investors \\
\hline Fig. 1. Stages of venture activity
\end{tabular}

When conducting venture activities, there is always a need for effective risk management of venture financing. Risk management is one of the main areas of activity in which a venture manager must have knowledge.

In general, venture management is a purposeful influence on the team of employees or individual performers to ensure the process of creating and commercializing the results of research and development, launching new competitive technologies, goods, services, ensuring the achievement of certain goals of the organization, managing innovative venture projects.

This type of management is focused on the constant search for opportunities to improve various products or services, it is a radically new innovation that has no analogues. The criterion of success here is the satisfaction of consumer needs; the speed of new products is more important than its quality. Another feature of venture management is that in such an enterprise, all employees must be involved in making management decisions, which leads to a high level of self-control among employees.

So, let's return to the topic of risk management in business. As mentioned earlier, this is the basis of venture management. All activities here are related to him and the ability to quickly adapt to changes in the external environment. Even motivating employees in the company is through risk reward schemes.

For V.G. Gerasimchuk and O.V. Schkolna [1] in a risk management organization, it is necessary, first, to identify the anticipated risks associated with venture capital. The organization of accounting, in general, in my opinion, is one of the most important ways to avoid problems with venture financing, because it helps to have detailed information about the sources of venture capital and the direction of its spending.

Secondly, it is necessary to analyze and evaluate the implementation of project risks. Also V.G. Gerasimchuk notes that in risk management it is necessary to choose the most effective methods of managing these risks and evaluate the results of management at each stage of the innovation project.

Since for Ukraine venture business is a relatively new type of entrepreneurship, this industry in our country is poorly developed. This is primarily due to the lack of qualified specialists in the field of venture investment and insufficient interest of the country's authorities, because we do not have a good basis for doing such business at the legislative level. Therefore, to begin the development of this industry, the government must develop laws that would make Ukraine a comfortable and safe place for venture financiers.
This will improve the Ukrainian economy not only through its own entrepreneurs, but also by attracting foreign investors.

\section{CONCLUSIONS}

Venture business has become a new type of investment that has a great impact on the growth of innovative economic development in the country. Because, despite the high risk and uncertainty of the end result, this business is extremely profitable, venture capital is seen as a factor in economic growth and recovery by bringing new products to market that meet societal needs. The work of a manager in this business is especially important. It is the venture manager who determines how risky a project is, analyzes the external and internal factors influencing the company's work, develops a business plan and monitors its implementation. An effective manager in a venture company is the key to success, an indicator of how much the investment provided by the business for an innovative project will pay off.

Ukrainian venture business is currently only developing, and is at an early stage of this development. An important task of the country is to focus on government support for venture business, especially its reputational component and the conditions of the company's growth in accordance with the global goals of sustainable development. Ukraine should start creating favorable conditions for venture investment as soon as possible. Because we believe that venture financing is very promising and important for the transition of our country to an innovative type of development, which in turn will inevitably lead to an improvement in the economy of Ukraine. Based on the definition of the economic essence of innovation, its main advantages are highlighted, and it is proved that venture activity at the present stage is a new investment mechanism. Namely, an effective tool for separating the money and other resources of different owners, a way to centralize them to solve problems of development of risky businesses with the concentration of efforts of all performers. To intensify it in Ukraine, it is necessary to form an infrastructure, the main elements of which will be internal, external and joint ventures, as well as venture funds. A special role is given to consulting and implementation companies that promote venture entrepreneurship. Our research shows that when comparing venture investments with other sources of financing investment projects of enterprises in today's difficult economic conditions, there is a high risk of nonreturn of invested funds and the need for additional financing while strategic business support. In order to fully enter Ukrainian products on the world market, the use of venture capital is an appropriate and necessary criterion 
for creating an optimal structure for financing economic reform projects.

The development of a strategy for sustainable development of the enterprise requires the study of market opportunities, their evaluation and implementation of the most acceptable areas of investment development, is the study of the best foreign experience in the implementation of venture investment agreements. Therefore, further research should be conducted in line with the formation of strategies for innovative development of enterprises on the basis of sustainable development.

\title{
$\underline{\text { References }}$
}

1. Herasymchuk V.H., Shkolna O.V. Risk management in foreign venture financing of innovative projects. Bulletin of the National University "Lviv Polytechnic". 2008. № 628. pp. 424-429. (in Ukrainian).

2. Petrenko V.S., Karnaushenko A.S. Financing of innovative youth entrepreneurship by attracting venture funds. Business Inform. 2020. № 7. pp. 242-248. (in Ukrainian).

3. Zamlynskyi V.A. Status and prospects for improving the information management of venture investment processes. Accounting and Finance. 2015. № 4. pp. 15-18. URL: http://nbuv.gov.ua/UJRN/Oif_apk_2015_4_4 (in Ukrainian).

4. Zamlynskyi V.A. Management of venture investment risks in the food sector. Economy: the realities of time. Scientific journal. 2016. № 1 (23). pp. 99-106. URL: https://economics.net.ua/files/archive/2016/No1/99.pdf

5. Zamlynskyi V.A. Role of analytical tools and venture capital in building marketing strategy of the agricultural and food sector development. Bulletin of Chernihiv State Technological University. 2014. № 3 (75). pp. 202-210. URL: https://economicvistnic.stu.cn.ua/tmppdf/1350.pdf (in Ukrainian).

6. Management vectors of successful business construction of the company in risk conditions / A.V. Buzunar, et.al. Challenges in Science of Nowadays: Proceedings of the 7th International Scientific and Practical Conference (Washington, USA, November 26-28, 2020). EnDeavours Publisher, 2020. pp. 148-158. DOI: https://ojs.ukrlogos.in.ua/index.php/interconf/article/view/6305

7. Zamlynskyi V.A. The current state and prospects of venture investment as a component of financial support for innovation in Ukraine. Foreign trade: economics, finance, law. 2014. № 5-6. pp. 172-179. URL: http://nbuv.gov.ua/UJRN/uazt_2014_5-6_19 (in Ukrainian).

\section{Список використаних джерел}

1. Герасимчук В.Г., Школьна О.В. Управління ризиками в іноземному венчурному фінансуванні інноваційних проектів. Вісник Національного університету “Львівська політехніка”. 2008. № 628. С. 424-429.

2. Петренко В.С., Карнаушенко А.С. Фінансування інноваційного молодіжного підприємництва шляхом залучення венчурних коштів. Журнал Бізнес Інформ. 2020. № 7. С. 242-248.

3. Замлинський В. А. Стан та перспективи удосконалення інформаційного забезпечення управління процесами венчурного інвестування. Облік і фінанси. 2015. № 4. С. 15-18. URL: http://nbuv.gov.ua/UJRN/Oif_apk_2015_4_4

4. Замлинський В.А. Управління ризиками венчурного інвестування в продовольчій сфері. Економіка: реалії часу. Науковий журнал. 2016. № 1 (23). С. 99-106. URL: https://economics.net.ua/files/archive/2016/No1/99.pdf

5. Замлинський В.А. Роль аналітичних інструментів та венчурного капіталу в побудові маркетингової стратегії розвитку аграрно-продовольчого сектору. Вісник Чернігівського державного технологічного університету. 2014. № 3 (75). С. 202210. URL: https://economic-vistnic.stu.cn.ua/tmppdf/1350.pdf

6. Management vectors of successful business construction of the company in risk conditions / A.V. Buzunar, et.al. Challenges in Science of Nowadays: Proceedings of the 7th International Scientific and Practical Conference (Washington, USA, November 26-28, 2020). EnDeavours Publisher, 2020. pp. 148-158. DOI: https://ojs.ukrlogos.in.ua/index.php/interconf/article/view/6305

7. Замлинський В.А. Сучасний стан та перспективи розвитку венчурного інвестування як складової фінансового забезпечення інноваційної діяльності України. Зовнішня торгівля: економіка, фінанси, право. 2014. № 5-6. C. 172-179. URL: http://nbuv.gov.ua/UJRN/uazt_2014_5-6_19

\author{
Катерина Валеріївна ПАСТУШЕНКО \\ студентка, Національний університет "Одеська політехніка" \\ ORCID: https://orcid.org/0000-0002-4604-694X
}

\author{
Адель Мохамед Абдула Султан АЛЬ-АЛІ \\ аспірант, Національний університет "Одеська політехніка" \\ ORCID: https://orcid.org/0000-0001-6577-6289
}

\author{
Віктор Анатолійович ЗАМЛИНСЬКИЙ \\ д.е.н., професор, викладач, Національний університет "Одеська політехніка" \\ ORCID: https://orcid.org/0000-0001-7642-2443 \\ e-mail: zam.agrariy@gmail.com
}

\section{ПЕРСПЕКТИВИ ВЕНЧУРНОГО ІНВЕСТУВАННЯ ІННОВАЦІЙНОЇ ДІЯЛЬНОСТІ В СУЧАСНИХ УМОВАХ СТІЙКОГО РОЗВИТКУ}

Стійкий розвиток економіки країни залежить від рівня інноваційної діяльності кожного підприємства. Підприємства мають незадовільний рівень інноваційного розвитку та їхні стратегії не відповідають иілям стійкого розвитку, що $\epsilon$ наслідком багаторічних хибних підходів до управління підприємствами та економікою краӥни. В сучасних умовах саме венчурне інвестування здатне подолати негативні тенденції, викликані недостатнім фінансуванням, низьким рівнем зацікавленості керівництва підприємств в інновачіях з високим рівнем ризику. У статті обтрунтовано актуальність залучення венчурних інвестицій для розвитку інноваційної діяльності підприсмств. Проаналізовано, чим венчурне 
інвестування відрізнясться від звичайного. Ретельно досліджено сучасний стан $і$ тенденції розвитку венчурного інвестування в Україні. Ідентифіковано проблеми та перешкоди функиіонування вітчизняного венчурного бізнесу. На підставі отриманих результатів дослідження та врахування кращьго іноземного досвіду сформовано комплексну поетапну технологію залучення венчурного капіталу інновачійними підприємствами на засадах стійкого розвитку. Розглянуто етапи венчурного фінансування та загалом діяльності венчурної компанії, механізми і стимули для підвищення зацікавленості у впровадженні інновацій у відповідності до ичілей стійкого розвитку на рівні підприємства. Досліджено те, який вплив має венчурне підприємництво на інновачійну діяльність компаній. А також акцентовано увагу на тому, як проводить управління організацією венчурний менеджер. Запропоновані шляхи формування, недоліки та переваги використання венчурного капіталу на глобалізованому етапі розвитку як засобу просування нових продуктів і технологій на світові ринки в контексті забезпечення сталого сочіально-економічного розвитку. У статті розглянуто сучасний стан венчурного інвестування та визначені напрями подальшого розвитку у розбудові сочіально-економічної системи.

Ключові слова: венчурний капітал, інвестиційні ресурси, інновачійно-інвестиційний механізм, джерела фінансування проектів, венчурні інвестиції, інновації, менеджмент, управління ризиками, економічний розвиток 